\title{
CATATAN SINGKAT MENGENAI UNSUR PERKOTAAN DI BLEGA*
}

\section{Lacas Partanda Koestoro}

Suatu obyek menarik dalam penulisan sejarah Indonesia kuna berkaitan dengan masalah pemukiman. Pemukiman merupakan lingkungan tempat manusia hidup serta melakukan berbagai macam aktifitas. Atau lebih lengkap lagi, pemukiman dapat berarti sebagai-tempat, ruang atau daerah tempat manusia berkumpul dan hidup bersama dengan memanfaatkan lingkungannya dalam mempertahankan, melangsungkan, dan mengembangkan hidupnya (Geertz, 1981 : 53).

Salah satu bentuk pemukiman dapat berupa kota. Perkataan kota tidak harus selalu diartikan dengan kehidupan modern yang dijumpai saat ini saja, sebaliknya masalah perkotaan dalam kaitannya dengan kehidupan di masa lampau lebih menitik-beratkan pada unsur-unsur asal-mula pertumbuhannya, pemilihan lokasi, situasi lingkungan, maupun sosialbudayanya (Djoko Soerjo, tanpa tahun : 2).

Daiam pembicaraan tentang asal-mula pertumbuhan sebuah kota, faktor-faktor ekonomi, politik, teknologi, serta latar-belakang sosialbudayanya merupakan bagian yang harus selalu diperhitungkan. Begitu pula halnya kalau pembicaraan menyinggung tentang lokasi maupun situasi lingkungan sebuah kota (Djoko Soerjo, tanpa tahun :2). Lokasi atau letak sebuah pemukiman adalah posisi pemukiman itu secara relatif dihubungkan dengan lingkungan sekitarnya yang ditentukan oleh reliefi topografi, iklim, kondisi tanah maupun vegetasi, serta hubungannya dengan air. Secara wajar, pemilihan lokasi sebuah pemukiman berupa kota mempunyai kaitan dengan keperluan khusus masyarakat pendukungnya. Keperluan khusus yang dimaksud adalah adaptasi pemanfaatanyang paling baik dengan kondisi alam-lingkungan, posisi strategis terhadap jalur lalu-lintas, dan motivasi politis, militer, maupun religi (Geertz, $1981: 53)$.

* Peninjauan arkeologi di Blega, Madura telah dilakukan oleh Balai Arkeologi Yogyakarta pada tahun 1982 berdasarkan informasi yang diberikan oleh Naroedji Achmad dan Basori, Staf Unit Pemugaran'Makam Aermata. 
Dari beberapa kasus yang dijumpai, tampak adanya perbedaan bentuk maupun wujud kota satu dengan kota lainnya yang disebabkan oleh ketidak-samaan kondisi beberapa faktor penentu timbulnya kota seperti yang telah disebutkan di atas. Sebagai misal, kota di pedalaman yang pada mulanya timbul sebagai akibat adanya aktifitas pertanian dan diikuti oleh aktifitas perdagangan. Oleh adanya perubahan dalam aktifitas politik, kota tadi kemudian berkembang sebagai pusat pemerintahan. Contoh yang jelas dari kasus tersebut adalah Majapahit (Soejatmi Satari, 1981 : 14) Kasus lain berlaku pada kota-kota pantai, terutama yang terletak di tepi muara sungai yang secara menyolok mampu berkembang sebagai kota pelabuhan yang makmur (Sartono Kartodirdjo, 1977:2). Pada mulanya tempat-tempat tersebut hanya merupakan lokasi penimbunan sementara hasil kerja pertanian daerah sekitarnya. Oleh karena lokasinya memungkinkan, tempat tersebut tumbuh lebih besar lagi sebagai pusat perdagangan yang tidak sekedar berfungsi sebagai tempat penimbunan hasil pertanian sebelum dibawa ke tempat lain, tetapi sekaligus berlaku sebagai pusat penyaluran berbagai jenis barang yang dikonsumsikan ke daerahdaerah lain di sekitarnya. Tugas yang dipikulnya itu segera diikuti dengan pembenahan berbagai sarana untuk lebih memantapkan kemampuannya. Kemudian, pihak yang merasa menguasainya juga melengkapi tempat itu dengan berbagai usaha pengamanan. Ujud usaha pengamanan itu dapat berupa benteng maupun penambahan kekuatan militer̀. Hal ini dapat diartikan sebagai usaha pengembangan dan pembenahan organisasi politik. Akhirnya tempat itu berubah sekaligus sebagai pusat pemerintahan.

Kalau di atas disebutkan kasus yang menunjukkan perkembangan sebuah pemukiman menjadi kota yang besar, dijumpai pula kasus lain yang justru kebalikannya. Terjadinya perubahan politik yang pada umumnya juga dipengaruhi oleh kondisi perekonomian dan sosial-budaya, dapat menyebabkan terhambatnya perkembangan sebuah kota. Bahkan menghancurkan sehingga tidak dapat lagi digunakan sebagai tempat yang memungkinkan orang hidup layak seperti masa-masa sebelumnya.

\section{II}

Penulisan sejarah Indonesia kuna, sebagian dilakukan dengan mengacu pada hasil kerja arkeologis. Arkeologi adalah cabang ilmu pengetahuan yang berusaha mengungkapkan kehidupan masa lampau melalui bendabenda budaya yang ditinggalkannya, dan berdasarkan hal itu dipandang 
perlu untuk melihat perkembangan suatu pemukiman. Pengetahuan tentang pasang-surutnya sebuah tempat yang disebut kota belakangan ini merupakan topik yang menarik dalam studi arkeologis. Usaha mengetahui sebab maupun akibat berkembang dan runtuhnya sebuah kota dapat didekati dan dimulai dengan sebuah penelitian arkeologis yang intensif atas sisa kebudayaan di suatu tempat.

Di Indonesia studi tentang perkotaan telah dilakukan pada beberapa situs yang keseluruhannya berasal dari masa berkembangnya pengaruh Hindu-Buddha maupun Islam. Contoh yang jelas terlihat dengan dilakukannya kegiatan arkeologis di bekas lokasi ibukota kerajaan Majapahit di Trowulan (Soejatmi Satari, 1977), maupun pusat pemerintahan kerajaan Banten yang berlokasi di Banten (Hasan Muarif Ambary, 1977).

Mengingat akan kondisi tinggalannya yang relatif lebih banyak dan mudah diketahui, studi arkeologis tentang perkotaan sebagai bagian dari obyek penelitian arkeologis di Indonesia lebih banyak berhubungan dengan sisa pusat pemukiman, perdagangan, dan pemerintahan dari masa pertumbuhan dan perkembangan Islam di Indonesia. Kenyataan ini juga dihubungkan dengan keyakinan bahwa memahami masalah yang berkenaan dengan arkeologi perkotaan dari suatu masa yang lebih dekat dengan masa kini akan bermanfaat bagi usaha pemahaman masalah serupa dari masa yang lebih tua (Mundardjito, 1978 : 8). Berkaitan dengan hal itu, dalam tulisan singkat ini akan dikenalkan salah satu sisa kejayaan masa itu yang berada di pulau Madura. Tempat yang dimaksud mungkin dapat dianggap sebagai salah satu dari beberapa bekas pusat pemukiman, perekonomian, dan sekaligus pusat pemerintahan yang berada di sepanjang pesisir selatan pulau Madura. Tidak seperti situs lain sejenisnya yang hingga saat ini masih menampakkan sisa kebesarannya, situs yang akan diketengahkan ini justru contoh dari kehancuran yang telah dialaminya.

\section{III}

Blega merupakan sebuah desa yang sekaligus berlaku sebagai nama kecamatan dalam wilayah administratif kabupaten Bangkalan, propinsi Jawa Timur. Daerah di bagian Madura Barat itu berada sekitar 40 kilometer di sebelah timur kota Bangkalan, di pertengahan jalan raya Bangkalan - Sampang. Kota kecamatan yang dibelah oleh aliran sungai Blega ini berjarak sekitar 12 kilometer dari garis pantai selatan pulau Madura. Letaknya berhadapan dengan kota Pasuruan dan Probolinggo di pesisir utara Jawa Timur yang dibatasi oleh Selat Madura. (Peta :1). 


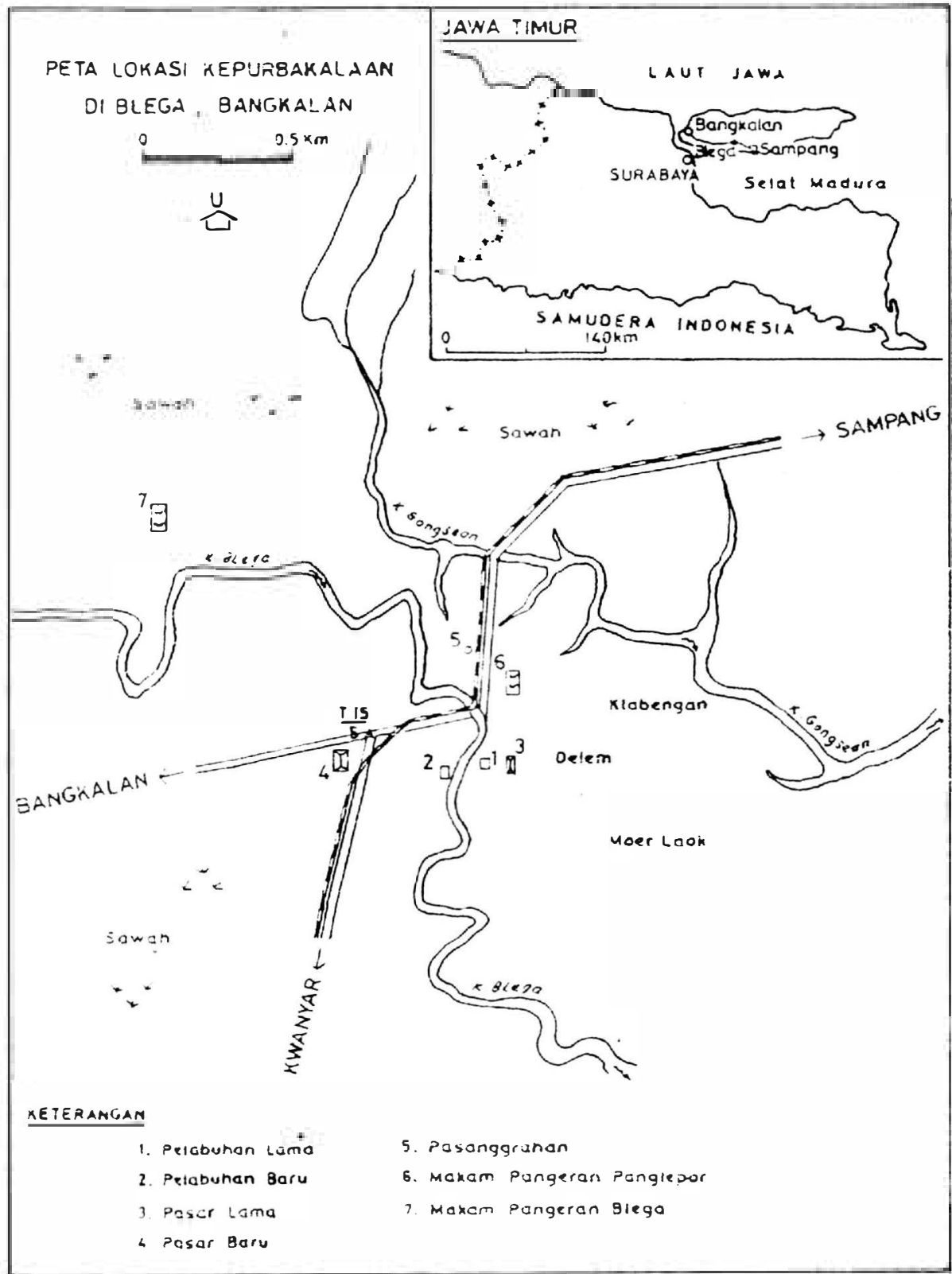


Sebagai daerah pesisir selatan pulau Madura, Blega yang berketinggian sekitar lima meter merupakan wilayah ber-relief halus dengan dua sungai mengalir di tengahnya. Kedua sungai yang mengalir dengan arah Barat-laut-tenggara itu masing-masing bernama sungai Blega di sebelah selatan dan sungai Gangsean di sebelah utara. Kedua sungai itu menyatu setelah membentuk daerah ber rawa-rawa di sebelah timur dan tenggara kota Blega. Muara kedua sungai yang menyatu itu berada sekitar 17 kilometer sebelah tenggara kota Blega.

Sungali Gangsean berukuran lebih kecil bila dibandingkan dengan sungai Blega di sebelah selatannya. Sungai tersebut hingga saat ini masih digunakan sebagai jalan air bagi perahu-perahu pengangkut garam dari daerah pertambakan garam di daerah pesisir ke Blega. Sungai Blega dengan ukuran yang lebih besar masih dimanfaatkan sebagai jalan air bagi penduduk di sebelah barat-laut dan tenggara kota Blega. Khusus pada hari-hari pasar kota Blega, di sungai itu terlihat kesibukan yang cukup padat dengan perahu-perahu pengangkut penumpang dan barang seperti garam. ikan, serta hasil pertanian. Beberapa tahun yang lalu, sungai Blega tadi masih berfungsi sebagai jalan air bagi perahu-perahu berukuran besar yang menjalani route Blega - Pasuruan, Probolinggo, Kenjeran (pemukiman nelayan di Surabaya), dan pelabuhan-pelabuhan lain di sepanjang pesisir selatan pulau Madura. Barang-barang yang diangkut biasanya terdiri dari garam, beras, ikan serta barang-barang pecahbelah yang dibuat dari tanah liat.

Sebagai sebuah desa yang sekaligus merupakan kota kecamatan, Blega telah dipadati dengan perumahan penduduk serta pertokoan di sepanjang jalan dalam kota ini. Pasar lama kota Blega berada tidak jauh dari jembatan besar dalam kota. Sekarang pasar telah dipindah ke sebelah baratnya, sedangkan di bekas lokasi pasar lama telah didirikan bangunan. Bagian utara, barat, dan selatan kota Blega masih merupakan lahan pertanian.

\section{IV}

Berdasarkan pada sumber tertulis seperti Babad Tanah Jawi dan Babad Songennep maupun ceritera rakyat pulau Madura, dapat diketahui beberapa hal yang berhubungan dengan tokoh maupun kekuasaan yang pernah ada di pulau Madura, khususnya di wilayah Madura Barat. Satu hal yang menarik, tokoh-tokoh tersebut selalu dikaitkan dengan raja Maja- 
pahit (Slametmulyana, $1979: 141$--2). Secara umum, gambaran tentang tokoh dan kekuasaan di Madura Barat, khususnya yang berkaitan dengan Blega, dapat disebutkan seperti di bawah ini.

Orang pertama di kalangan bangsawan Madura Barat yang memeluk agama Islam adalah Pangeran Pratanu pada tahun 1528 (Graaf \& Pigeaud, 174 : 171). Beliau naik tahta menggantikan ayahnya yang bernama Kyai Pragalbo pada tahun 1531 dengan nama Panembahan Lemah Duwur yang pusat kekuasaannya berada di Arosbaya (Sartono Kartodirdjo, 1973 :4 ). Pada masa pemerintahannya itu, beliau memperluas kekuasaannya atas Blega dan Sampang (Graaf \& Pigeaud 1974 : 172). Selain itu, Sumenep dan Pamekasan pun berada di bawah pengaruh kekuasaannya ( $\mathbf{P a}^{\prime} \mathbf{K a}$ mar. 1926: 235).

Tampaknya, pemelukan agama Islam oleh Panembahan Lemah Duwur dapk dianggap pula sebagai titik awal pengakuan Madura Barat atas kekuasaan Demak sebagai pengganti Majapahit. Hal ini kalau dihubungkan dengan sumber yang menyatakan hahwa penelukan agama itu didahului dengan dikirimnya seorang utusan ke Demak untuk mempelajari agama tersebut dari Sunan Kudus (Pa' Kanar, 1926: 231 -. 4). Selain iru, di luar adanya hal-hal khusus, mungkin pemelukan agama Islam oleh lainemhahan Lemah Duwur dilandasi oleh keinginannya menghindari serangan Demak. seperti yang terjadi terhadap beberapa kerajaan vasal Majapahit yang tidak atau belum memeluk agama lslan. Bahkan diketahui pula bahwa Panembahan Lemah Duwur belakangan ikut mengirimkan pasukan datlam usaha Demak menaklukan beherapa kerajaan vasal itu (Graaf \& Pigeaud, $1974:$ 172).

Pada tahun 1592. Panembahan Lemah Duwur digantikan oleh anakm a yang hernama Pangeran Tengah (Sartono Kartodirdjo, 197.3: 4). hasil perkawinannya dengan triman dari raja Pajang (Graaf \& Pigeaud. 1974 : 173). Pada awal pemerintahannya. Pangeran Tengah harus berperang melawan Blega dan Sampang. Ketika itu Blega berada di bawah pemerintahan adiknya yang bernama Sakatah (Graaf \& Pigeaud, $1974: 173$ ), atau dikenal pula dengan Pangeran Blega atau Kaden Koro, yakni anak Panembahan Lemah Duwur dengan Katu Ibu yang berasal dari Madegan, Sampang ( $\mathrm{Pa}^{\prime}$ Kamar, 1926 : 2134 ). Usaha memadamkan perlawanan yang dilakukan oleh Pangeran Blega itu berlangsung cukup lama. Setelah Patih Macan yang diandalkan oleh Pangeran Blega dapat dikalahkan dengan suatu tipu muslihat, Pangeran Tengah berhasil mematahkan usaha Blega melepaskan diri dari pengaruh kekuatan Arosbaya ( $\mathrm{Pa}^{\prime}$ Kamar, 1926 : 235). 
Pangeran Tengah diperkirakan meninggal pada tahun 1620 (Graaf \& Pigeaud. 1974 : 173) atau 1621 dan selanjutnya pemerintahan dipegang oleh saudara laki-lakinya yang bernama Pangeran Mas karena putera mahkota yang bernama Raden Prasena masih kecil (Sartono Kartodirdjo. 1973 : 4). Pangeran Mas adalah putera Panembahan Lemah Duwur dengan Ratu Ibu dari Sampang (Pa' Kamar, 1926 : 234).

Suatu kejadian besar yang berlangsung pada masa pemerintahan Pangeran Mas adalah serangan pasukan Mataram yang waktu itu di bawah pemerintahan Sultan Agung atas pulau Mádura. Akibat serangan yang terjadi pada tahun 1624 itu, beberapa kota di bagian harat pulau Madura seperti Bangkalan, Arosbaya, Blega dan Sampang diduduki oleh pasukan Mataram (Sutjipto Tjiptoatmodjo, 1983 : 299). Pangeran Blega yang juga ikut mengerahkan pasukan Blega melawan serangan Mataram ditangkap dan kemudian dibunuh oleh pasukan Mataram (Pa' Kamar, $1926: 235$-. 6).

Lama setelah kejadian tersebut di atas, tidak terdengar lagi herita tentang Blega. Sumber lain belakangan menyehutkan bahwa pada tahun 1746, bersama-sama dengan kota pantai lain di sepanjang pesisir selatan pulau Madura seperti Arosbaya. Bangkalan, Kwanyar dan Sampany, Blega merupakan kota pelabuhan yang cukup banyak mendatangkan penghasilan bagi penguasanya. Oleh sebab itu. Kompeni memaksa ayar urusan kesyahbandaran Blega dan kota-kota pantai lainnya itu dipegang olehnya (Sutjipto Tjiptoatmodjo, 1983 : 435). Hal ini nierupakan bukti bahwa Blega masih memegang peranan yang cukup penting dalam perdagangan yang berlangsung di sekitar selat Madura.

Akibat perlawanan yang dilakukan oleh Pangeran Cakraningrat IV. penguasa Madura Barat, terhadap Kompeni. kota-kota Sampang. Blega. Kwanyar, dan Sembilangan diserang oleh Kompeni (Sutjipto Tjiptoatmodjo, 1983 : 299). Tampaknya hal itu merupakan salah satu sebab dari kemunduran Blega sebagai sebuah pusat perdagangan di pesisir selatan pulau Madura. Peperangan tentunya sangat mengganggu perkembangan kota tersebut bahkan menimbulkan kemacetan dalam perdagangan. Bangunan dalam kota mengalami kerusakan dan kehancuran. Pedaganypedagang besar mengungsi ke kota-kota pantai lain yang dipandang aman. tempat mereka dapat melanjutkan usahanya.

Pada tahun 1815, secara tegas Kompeni melaksanakan pembagian wilayah kekuasaan Madura menjadi tiga distrik. Ketiga distrik tersebut masing-masing adalah Bangkalan, Blega, dan Sampang (Sutjipto Tjiptoatmodjo, 1983 : 299). Pembagian wilayah yang diikuti dengan tindakan 
pengawasan yang ketat tentunya dilakukan sebagai usaha mematahkan keinginan Madura Barat untuk melepaskan diri dari cengkeraman Kompeni. Usaha ini berhasil baik karena pada masa-masa berikutnya dari ketiga daerah tersebut tidak terdengar lagi adanya perlawanan yang ditujukan terhadap Kompeni. Sebaliknya, akibat lain bagi Blega, seperti juga halnya dengan Bangkalan maupun Sampang, adalah hilangnya kesempatan untuk mengembalikan posisinya ke kejayaan semula sebagai kota pelabuhan yang bebas. Terlebih-lebih dengan munculnya kota Surabaya yang oleh Kompeni dijadikan pusat kegiatan perdagangan yang mampu menggeser kedudukan kota-kota pelabuhan yang telah ada sebelumnya. (Djoko Soerjo, tanpa tahun : 11).

\section{$\mathbf{V}$}

Di Blega dan sekitarnya masih dijumpai beberapa unsur yang keseluruhannya menunjukkan kaitannya sebagai sebuah pemukiman dengan berbagai aktifitas sosial-budayanya. Unsur-unsur yang merupakan tinggalan arkeologis maupun toponim itu dapat dikelompokkan sebagai berikut :

1. pelabuhan

2. pasar

3. tempat tinggal

4. pintu gerbang

5. makam

Uraian tentang kelompok-kelompok tinggalan tersebut di atas akan dimulai dari pelabuhan, mengingat letak serta fungsinya yang dapat dianggap sebagai pusat kegiatan daerah tersebut dahulu.

1. Pelabuhan.

Pelabuhan lama, menurut keterangan yang disampaikan penduduk, terletak di sebelah tenggara jembatan di tengah kota Blega. Lokasi bekas pelabuhan itu sekarang merupakan pemukiman penduduk. Hanya sebagian kecil dari lokasi itu saja yang hingga saat ini masih dimanfaatkan sebagai tempat menurunkan ikan dari laut dan tambak daerah sekitar pada sore hari. Letak bekas pelabuhan itu sekarang termasuk dalam wilayah kampung Delem. Di lokasi ini pernah ditemukan keramik asing, utuh maupun pecahan, serta bata berukuran besar dan balok batuan andesit.

Pelabuhan baru yang pada hari-hari pasar kota Blega menampung cukup banyak perahu, berada di sebelah barat bekas lokasi pelabuhan 
lama di tepi sungai Blega. Yang dikatakan sebagai pelabuhan baru tidak lebih dari tanggul sungai. Hanya karena lokasinya lebih dekat ke pasar, tempat tersebut ramai disinggahi perahu-perahu.

\section{Pasar.}

Pasar lama juga perada dalam wilayah kampung Delem, berhadapan dengan pelabuhan lama. Di atas lokasi bekas pasar lama, sekarang telah didirikan bangunan Puskesmas dan sekolah dasar serta pemukiman pen. duduk.

Pasar yang baru telah didirikan agak jauh di sebelah barat pasar lama. Letaknya di sudut simpang tiga jalan raya Bangkalan - Sampang dan Blega - Kwanyar. Pindahnya pasar ke tempat yang baru itu merupakan salah satu sebab beralihnya tempat berlabuh perahu-perahu ke seberang barat sungai Blega.

\section{Tempat tinggal}

Ada dua unit tempat tinggal yang merupakan bagian penting dari kota Blega. Unit tempat tinggal pertama yang sekarang hanya tinggal nama tempat saja adalah Delem.

Delem merupakan nama kampung yang terletak di antara sungai Blega dan sungai Gangsean, di sebelah timur jalan raya Bangkalan - Sampang. Dalam wilayah kampung Delem itu terdapat lokasi bekas pelabuhan dan pasar la ma kota Blega.

Dalam bahasa Madura, delem memiliki arti rumah raja/ratu. Penduduk setempat percaya bahwa di lokasi itulah dahulu pernah berdiri kraton penguasa Blega. Hingga saat ini penduduk sering menjumpai struktur bata yang hata-batanya memiliki ukuran cukup besar. Selain itu juga didapati beberapa balok batuan andesit. Sebuah di antara balok batuan andesit itu diletakkan di halaman Koramil Blega.

Unit tinggalan lain yang berupa sisa tempat tinggal adalah pasanggrahan, letaknya di sebelah barat-laut pelabuhan lama, di tepi barat jalan raya Bangkalan - Sampang. Lokasi pasanggrahan itu termasuk dalam wilayah kampungKauman. Salah satu sisa bangunannya, setelah mengalami perbaikan, saat ini digunakan sebagai kantor polisi. Sebelum digunakan sebagai kantor polisi, bangunan tadi dipakai sebagai tempat potosan $($ = putusan ). Mungkin semacam kantor pengadilan tempat hakim dan jaksa memutuskan hukuman. Cerita setempat menyebutkan bahwa plasanggrahan itu dahulu digunakan sebagai tempat peristirahatan penguasa Bangkalan, penguasa Sampang, dan Patih Macan (Pangeran Pang- 
lepor). Menurut sumber tertulis Madura, Patih Macan atau Pangeran Panglepor adalah patih Blega yang sangat diandalkan pada masa pemerintahan Pangeran Blega.

\section{Pintu gerbang.}

Sebagai kelengkapan delem (= tempat tinggal|raja/ratu), di sekitar kampung Delem menurut ceritera terdapat empat buah pintu gerbang. Keempat pintu gerbang itu masing-masing disebut :

a. bang moer laok, yang artinya pintu gerbang tenggara.

b. bang temoeran, pintu gerbang timur.

c. bang dejanah, pintu gerbang utara dan

d. klabengan, yang artinya pintu gerbang barat.

Di sebelah tenggara kampung Delem masih dijumpai nama tempat Moer Laok. Di tempat tersebut sering dijumpai bata-bata berukuran besar. Sedangkan di sebelah timur kampung Delem, di tepi barat sungai Gangsean, terdapat nama kampung Klabengan. Seperti halnya dengan di Moer Laok, di tempat itu yang sekarang menjadi pemukiman penduduk, pernah ditemui struktur bata yang ukuran batanya sama dengan yang dijumpai di Moer Laok.

\section{Makam.}

Di Blega terdapat dua unit makam yang masing-masing merupakan kompleks makam Pangeran Panglepor dan kompleks makam Pangeran Blega. Kompleks makam Pangeran Panglepor terletak di belakang kantor pegadaian Blega, di sebelah utara bekas pelabuhan lama, sedangkan kompleks makam Pangeran Blega berada di sebelah barat-laut Blega, dalam wilayah desa Karangkemasan.

Kompleks makam Pangeran Panglepor memiliki dua makam tokoh utama, yakni makam Pangeran Panglepor dan isterinya. Makam yang hingga kini masih dikeramatkan sementara penduduk itu merupakan tumpukan bata yang tingginya hampir dua meter. Nisan bagi makam Panglepor dibuat dari batu karang yang berwarna putih dẹngan hiasan sekedarnya, sedang nisan bagi makam isterinya dibuat dari batu putih tanpa hiasan. Kedua makam utama itu tidak bercungkub dan di sekitarnya dipenuhi oleh makam penduduk.

Kompleks makam Pangeran Blega berjarak sekitar satu setengah kilometer dari pusat kota Blega. Denahnya berbentuk empat persegi panjang dengan orientasi utara - selatan, terbagi atas tiga halaman dan dikelilingi oleh tembok bata dan batu putih. Penyusunan tembok bata dan 
batu putih, jirat dan nisan, gapura dan kellr, semuanya dilakukan tanpa menggunakan perekat.

Sebuah gapura bentar dalam kompleks ini dihiasi dengan ukiran berupa medalion bujur yang dipenuhi motif tumbuh-tumbuhan di dalamnya. Sedangkan pada kelir di bagian utara gapura terdapat hiasan kerawang berbentuk roset/palang Yunani pada panel-panelnya. Di bagian tengah roset itu terdapat medalion bulat yang sekelilingnya di beri ukiran bermotif tumbuh-tumbuhan. Bagian samping kellr dihiasi motif geometris seperti belah ketupat medalion bulat dan bujur yang dipenuhi dengan motif sulur-suluran. (Foto : 1 ).

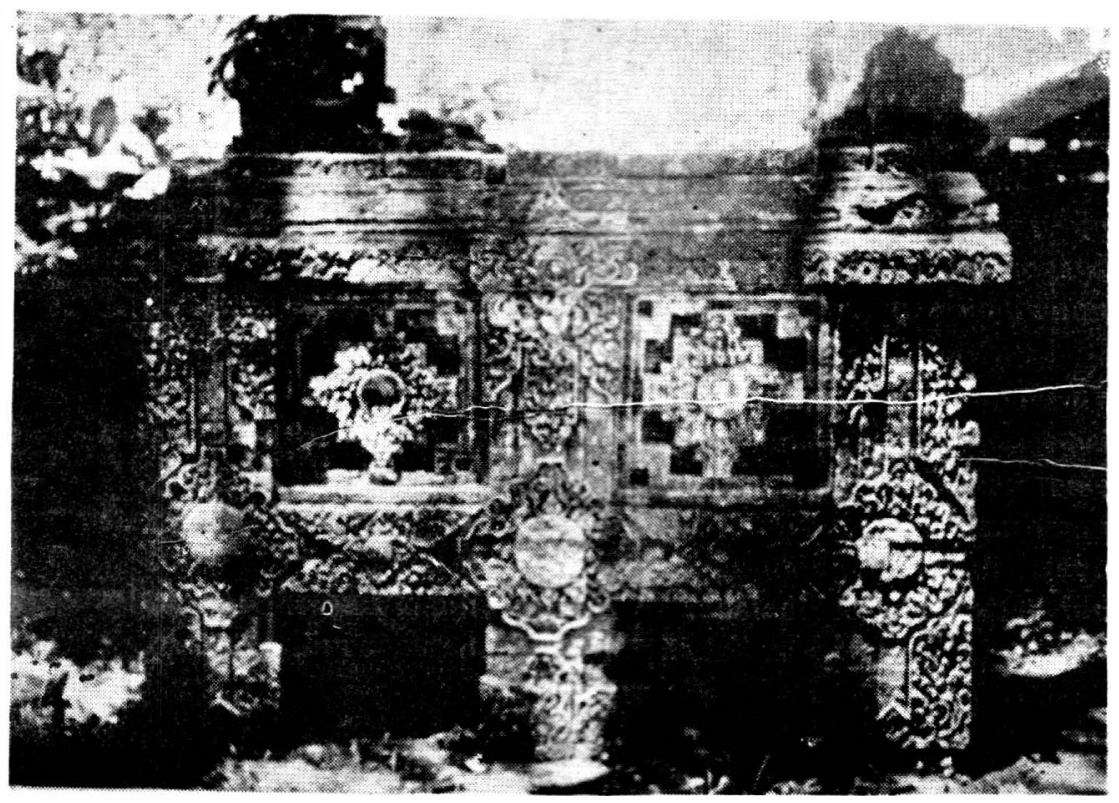

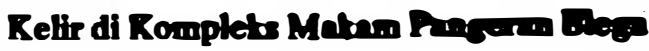

Pada halaman ketiga kompleks makam itu terdapat semacam batur dengan makam Pangeran Blega dan permaisuri di atasnya. Seperti halnya dengan makam-makam lain dalam kompleks ini, makam Pangeran Blega serta permaisurinya memiliki nisan berbentuk kurawal yang dibuat dari batu putih. Selain nisan-nisan dari batu putih, diluar kompleks makam itu terdapat dua buah makam tanpa jirat yang nisannya dibuat dari batu karang. Bentuk dasar nisan itu adalah kurawal tetapi dengan variasi berupa 
bulatan di bagian tengah dan setengah bulatan di atasnya. Bagian tepi nisan dihiasi dengan bulatan-bulatan kecil. Seperti halnya dengan makammakam di kompleks Pangeran Panglepor, makam di kompleks inipun tidak diberi cungkub.

\section{VI.}

Daribeberapa unsur yang berupa tinggalan arkeologis serta toponim, tidak berlebihan kalau ada perkiraan bahwa kraton Blega memiliki arah hadap ke utara. Hal ini dapat di analogikan dengan beberapa pola perkotaan pusat - pusat pemerintahan dari masa pertumbuhan dan perkembangan Islam di Indonesia, yang penempatan bangunan masjidnya berada di sebelah barat-laut bangunan kraton. Di Blega, nama kampung Kauman terletak di sebelah barat-laut kampung Delem. Nama Kauman mengingatkan pada nama tempat yang erat kaitannya dengan kelompok-kelompok masyarakat dari kalangan pemuka agama Islam dan pada umumnya di dalam areal itu terdapat masjid.

Walaupun ada anggapan bahwa pola perkotaan dari masa pertumbuhan dan perkembangan Islam di Indonesia memiliki pola dasar yang sama, pada kenyatannya sering terdapat perkecualian yang disebabkan berbagai faktor lingkungan. Di Blega, keletakan pasar tidak di sebelah utara bangunan kraton, seperti yang terlihat pada pola perkotaan di Kotagede dan Yogyakarta. Hal itu tampaknya harus dimengerti dengan melihat adanya sungai di sebelah barat kampung Delem, dengan pelabuhan sebagai pusat kegiatan penimbunan barang-barang yang didagangkan. Pasar di Blega letaknya berhadapan dengan pelabuhan, tidak jauh dari kraton.

\section{VII}

Hingga saat ini, kegiatan arkeologis terhadap situs-situs di pulau Madura tampaknya belum begitu luas. Mungkin situs Blega dapat diajukan sebagai salah satu alternatif pelaksanaan penelitian arkeologi yang berkaitan dengan studi perkotaan. Sasaran penelitian tersebut tentunya adalah pengungkapan kembali hasil budaya masyarakat Blega yang pernah menjadi pusat kegiatan selama kurun waktu yang cukup lama, khususnya pada masa pertumbuhan dan perkembangan Islam di Indonesia. 
Mungkin dengan dilakukannya penelitian di situs Blega, akan dapat diperoleh keterangan yang lebih tegas akan ciri, sifat maupun watak perkotaan Blega pada awal, pertumbuhan, perkembangan, serta masa kesuramannya. Hal ini sekaligus juga berarti diperolehnya kejelasan akan besar-kecilnya pengaruh luar Madura yang masuk. diserap dan dicerna masyarakat pendukungnya untuk diberlakukan sebagai bagian dari kehidupannya. Untuk lingkup yang lebih luas, situs Blega dapat dijadikan salah satu sarana untuk mengetahui sifat atau ciri umum pusat-pusat pemukiman pantai di Indonesia. 


\section{K E P U S T A K A A N}

Djoko Soerjo, Kota-kota Di Jawa Pada Abad 17 - 19, Yogyakarta: Proyek Javanologi.

Geertz, Hildred. 1981. Aneka Budaya Dan Komunitas Di indonesia. Jakarta: Yayasan Ilmu-ilmu Sosial \& FIS Ui.

Goenadi Nitihaminoto \& Novida Abbas. 1981/ 1982. Laporan Survai Pantai Utara Jawa Tengah Dan Jawa Timur. Yogyakarta: Balai Arkeologi Yogyakarta. Tidak diterbitkan.

Graaf, H.J. De \& Th. G. Th. Pigeaud, 1974. "De Eerste Moslimse Vorstendommen Op Java" V.K.I., Deel 69. 's-Gravenhage: Martinus Nijhoff.

Hasan Muarif Ambary, 1977. Tinjauan Tentang Penelitian Perkotaan Banten Lama, Makalah dalam Pertemuan ilmiah Arkeologi di Jakarta.

Lucas P. Koestoro, 1981/ 1982. Laporan Peninjauan Kepurbakalaan Di Arosbaya Dan Blega, Bangkalan. Yogyakarta: Balai Arkeologi Yogyakarta. Tidak diterbitkan.

Mundardjito, Hasan Muarif Ambary \& Hasan Djafar, 1978. "Laporan Penelitian Arkeologi Banten 1976". Berita Penelitian Arkeologi, Nomor 18, Jakarta Proyek Penelitian dan Penggalian Purbakala.

Pa' Kamar, 1926. "Geschiedenis Van Madoera", Djawa, Tahun Keenam, Weltevreden: Java instituut, hal. 231 - 250.

Sartono Kartodirdjo (Ed.), 1973. Sejarah Perlawanan-Perlawanan Terhadap Kolonialisme. Jakarta: Pusat Sejarah ABRi. 
Sartono Kartodirdjo (Ed.), 1977 Masyarakat Kuno \& KelompokKelompok Sosial, Jakarta: Bairatara Karya Aksara.

Slametmulyana, Negarakertagama Dan Tafsir Sejarahnya, Jakarta: Bhratara Karya Aksara.

Soejatmi Satari, 1977. Beberapa Data Sebagai Sumbangan Untuk Penelitian Bekas Kraton Majapahit. Makalah dalam Pertemuan Ilmiah Arkeologi di Jakarta.

Soejatmi Satari, 1981. Penelitian Pola Pemukiman di Indonesia. Makalah dalam Rapat Evaluasi Metode Penelitian Arkeologi di Yogyakarta.

Sutjipto Tjiptoatmodjo, F.A., 1983. Kota-kota Pantai Di Sekitar Selat Madura (Abad XVII Sampai Medio Abad XIX), Disertasi pada UGM di Yogyakarta. 


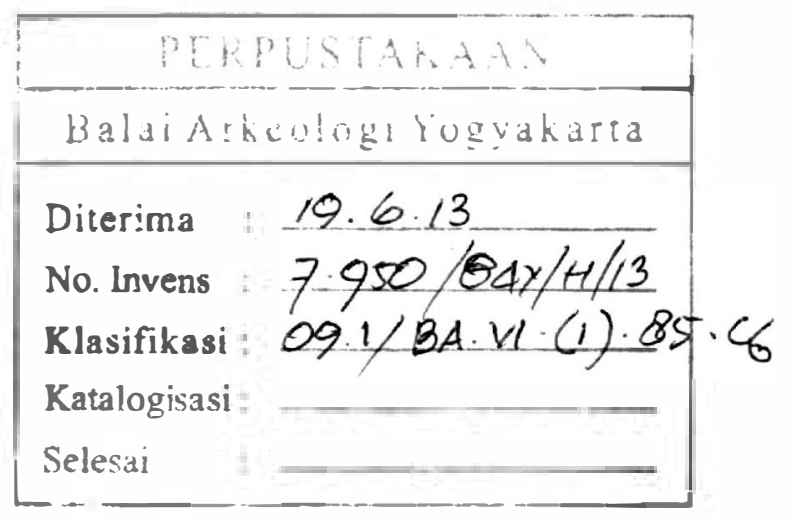

Sumbangsih Offset, Papringan telp. 4718 Yogyakarta. 